\title{
Collaborative Teamwork in Crossdisciplinarity
}

\author{
Renée-Pascale Laberge \\ Complementary Studies Center, Department of Mathematical and Industrial Engineering, Polytechnique Montreal, Canada
}

Copyright $(2016$ by authors, all rights reserved. Authors agree that this article remains permanently open access under the terms of the Creative Commons Attribution License 4.0 International License

\begin{abstract}
Polytechnique Montréal has integrated an approach of teamwork in its twelve engineering programs, in the bachelor's degree program since 2005. Students must take a compulsory 45 hours course on teamwork and are then accompanied with team coaching throughout the four years program, in all the engineering integration projects. These integration projects are generally ones in which, over a session, the students work in teams to conceive an engineering project. From the creation of a model of a bridge, to the production of a miniature robot, or the design of an industrial product, the projects are as varied as the teams. Within the framework of these projects ( 1 per year), a group communication specialist meets every team for approximately 60 minutes. This process promotes the transfer of the accumulated knowledge acquired in the teamwork course to their projects and helps identify the group processes at play in their teamwork dynamics. These meetings incite the members of a team to explain their work method, their internal organization, their decision-making process, as well as to give feedback with the objective of finding solutions and taking action. The specialist, during this type of follow-up, acts as a mentor. Along with these meetings is added a service of "crisis management" for the teams in difficulty. The specialist attempts, with the team, to define as clearly as possible the dynamic and relational aspects of the problems and they focus on helping the group find a solution for better teamwork. During this type of follow-up, the specialist acts as an advisor. Hence, an experiential approach and a solution-oriented approach used throughout the learning process allow the development of skills in teamwork for the students. The objective pursued by this article is to present an innovative formula used by Polytechnique Montréal and to demonstrate by clear examples how it allows the development of skills in teamwork in all the scientific disciplines. In fact, the experiential approach and the approach oriented to the solutions used at Polytechnique Montréal could be transferred in disciplines as varied as design, computer science, engineering or even ergonomics.
\end{abstract}

Keywords Interpersonal
Approach of collaborative Communication, Teamwork
Teamwork, Dynamics,
Experiential Approach, Solution-oriented Approach and Team Coaching

\section{Introduction}

Private and public organizations are in full mutation. The growing complexities of the work environment are causing such great changes that it is difficult for someone to manage, elaborate solutions and to make decisions on their own. More and more, the working world is using collaborative style management based on collaboration; multidisciplinary and interdisciplinary teams seem to be becoming the norm [19]. In Québec, as elsewhere in North America, the engineering world has transformed itself in recent years. Where once the engineer worked alone, there is now a team. Harvey and Green [24] point-out that according to the disciplinary competencies, abilities related to teamwork constitute the second most important characteristic taken into consideration by employers at the moment a new candidate is chosen. The expectations of the engineering milieu in regards to work team competencies are becoming more demanding. That explains why certain engineering programs are looking to integrate group work training. The production of work in teams within courses has grown in popularity because it allows the integration of pedagogical approaches that correspond to the expectations of the workplace $[19,9$, 36]. Therefore, it has become important to explore the conditions that will allow the integration of new competencies and pedagogical approaches in team work in engineering schools.

In 2003, Polytechnique Montréal integrated, entirely and massively, in the course curriculum for the students of 12 of its undergraduate programs, some teaching methods linked to the needs of the job market. Among the objectives of its new training project put in place since 2005, the will to reinforce the development of teamwork abilities is certainly considered to be a priority. Interpersonal abilities were identified as one of the necessary strengths of the specifications of the training project. Since 2006, 2 credits have been accorded for the integration of teamwork (TW) 
and interpersonal communications (IC) courses in the undergraduate programs, which demonstrates to students that these competencies are of the utmost importance in their training to become engineers. Chart 1 presents the layout of the courses ( 2 credits and $1+1$ credit) in 12 Engineering programs. A 45 hours mandatory course is the foundation of a team coaching over a 4 years period in every engineering integration project. A team of specialists in interpersonal communication and small groups are responsible for teaching the courses and the monitoring of the teams in their integration projects. This innovative and personal approach aims to motivate students to put into practice these skills and this approach can be applied to disciplines as varied as Design, Computer Science, Engineering, and even Ergonomics. Figure 1 shows the course structure in the 12 engineering programs.

\begin{tabular}{|c|c|}
\hline $\begin{array}{c}2 \text { credit course (3hours X } 13 \\
\text { weeks) }\end{array}$ & $\begin{array}{c}1+1 \text { credit course (3hours } \times 7 \\
\text { weeks) }\end{array}$ \\
\hline $\begin{array}{l}\text { Course integrated in } \\
\text { integration project } \\
\text { session/1st year): } \\
-\quad \text { Aerospace, Biomedical, } \\
\text { Chemical and Electrical } \\
\text { Engineering (IC\&TW) } \\
\text { Course only (1st session/1st } \\
\text { year): } \\
\text { - Industrial, Mechanical and } \\
\text { Physics Engineering (IC\&TW) }\end{array}$ & $\begin{array}{l}\text { Course integrated in integration } \\
\text { project (1st session/1 st year): } \\
-\quad \text { Computer and Software } \\
\text { Engineering (IC) } \\
\text { Course integrated in integration } \\
\text { project }(1 \text { st session/2nd year): } \\
- \text { Computer and Software } \\
\text { Engineering (TW) } \\
\text { Course only (1st session/1st year): } \\
- \text { Civil, Geological and Mining } \\
\text { Engineering (IC) } \\
\text { Course only (2 } 2^{\text {nd }} \text { session/1st year): } \\
\text { Civil, Geological and Mining } \\
\text { Engineering (TW) }\end{array}$ \\
\hline
\end{tabular}

Figure 1. course structure in the 12 engineering programs

\section{Teamwork Courses at Polytechnique Montréal}

Teamwork provides individuals with the opportunity to get to know themselves better, to use their leadership, to take on responsibilities in relation to others, to promote their ideas and points of view, to open up to others, to listen and question the ideas of others. Reaching these objectives necessitates, however, an openness and effort on the part of the students. Our experience has shown us that to simply ask a group of students to execute a task and produce a report does not guarantee that the group will reach their objectives. To develop this type of ability, the students have to learn to concentrate not only on the task to be accomplished, but also on themselves, on the interactions and the group dynamics taking place in their work groups. The development of introspection seems to be essential to provoking the change and the awakening of a level of consciousness that is necessary for collaboration $[50,42]$. The students must learn to look at each other, to question themselves while identifying their strengths and weaknesses (individual and team) and to determine objectives for realistic, concrete changes to develop their abilities and eventually their competencies.

\subsection{An Experiential Approach Oriented towards Change}

A founding principle underlying the training is the idea that through experience comes knowledge. We can link this to the idea that comes from Confucius, "I hear and I forget. I see and I remember. I do and I understand." Each class begins with a practical activity that places the student in a difficult situation that necessitates the use of interpersonal skills and/or teamwork. The experience facilitates the emergence of certain phenomena that are then discussed as a group and colored with numerous examples drawn from the engineering milieu. We have established that the student, who has lived the situation, is able to grasp the depth and importance of the notions that they are taught. As a result, the concepts generally associated with human science are transferred through practice and are, generally, no longer considered as an abstract idea by the students. That is why the pedagogy of this type of training combines a practical dimension and a theoretical dimension. The learning objectives are at once both of a cognitive and behavioral nature, of the order of knowledge, of know-how and inter-personal skills. This enunciation aims to allow students to learn cognitively and experientially from these phenomena and to develop their reading capacity and develop certain skills in action.

Therefore, the development of teamwork skills at Polytechnique Montréal stems not from technical learning but through experience. This type of training implies a modification of attitudes, beliefs and personal values demanding a strong involvement from the students. As is the modern tendency in teaching, our methods are student-centered and require a great deal of involvement on their part [4].

Kegan [26] states that the complexities of today's world and the need's of the working world necessitate, beyond new skills, the attainment of a higher level of consciousness, that is to say, a change in the way we interpret and react to our world. Young [50], for his part, affirms that "transformational" leadership, is strongly linked to the level of consciousness of management. It is they who are capable of considering a multitude of points of view, since they can take into consideration that various interpretations of the same event can be simultaneously valid. They adopt a systematic mentality, looking for interdependencies rather than the relationships of cause and effect and focus not only on results, but also on the process [12]. As Snowden and Boone [42] says it so well, "circumstances change, however, and as they become more complex, the simplification can fail. Good leadership, for example, is not a one-size-fits-all proposition". While seeking the development of a higher level of consciousness and the skills that appear to flow there from, three principles are at the base of the team work training: 1) we learn in interaction, 2) we can improve our abilities while experimenting with new behaviors and asking our colleagues for feedback, 3) we develop our level of consciousness and our reflex to improve as we engage in a process of self and group analysis, as well as identifying and 
practicing our objectives of change.

This change oriented approach is reflected more particularly, by the student's taking responsibility for the development of their team work competencies $[38,31,46,17$, 41]. The student is encouraged to question their abilities, to self-evaluate and to define a concrete strategy to practice their development. For example, a student who has identified that their problem as a listener is mainly caused by the fact that they constantly argue what others say without letting the other finish what they have to say, could challenge themselves to concentrate on listening to others all the way to the end of their point without arguing discussing or even countering the point in their mind 3 times during the week. They could simply place the word listen on a piece of paper in front of him so that they can see the objective and stick to it. The desired objective of this pedagogical approach is obviously not to develop the skills during the week, but to develop a reflex of self-training of the progression of the competencies in the student based on change. The competencies are developed through questioning, insights and the practicing of new behaviours. Hence, the courses affect the whole person, their way of knowing, doing and being and are part of a short, medium and long-term process.

\subsection{Some Concepts Taught and their Objectives}

Two important interdependent themes are touched upon in the 45 hours training through teamwork. Firstly, some concepts linked to interpersonal communication (IC) are presented: mental models (mental maps), perceptions, emotional and relational intelligence, listening, critical and constructive feedback and conflict management $[34,49,6,7$, $3,5,15,27,11,48,10,47,35,23,29,25]$. We consider these skills to be the foundation of collaborative team behaviour. Secondly, the concepts associated with the literature are addressed in small groups through team work: some models of small teams, the characteristics of a team, norms, roles, modes of interaction, facilitation, cohesion, power and leadership [33, 8, 45, 43, 1, 24, 2, 32, 40, 28, 42]. These notions foster understanding of group dynamics, important elements that it is composed of, and its management.

\subsubsection{Mental Models}

For Wind and Cook [48], mental models represent the way that we look at the world. This mental map helps us to orient our way of entering into communication, of understanding and seizing the world. A reflection on the influence of our mental models allows a transformation of our beliefs and assumptions that underlie our decisions and our openness to the ideas of others. Since we forget that we function with mental models, the objective is to remind ourselves that we do not deal directly with reality. As the Talmud says, we do not live in the world as it is, but rather as we are. Take the example of a student who is not able to understand that his interpretation of a conflict situation in a team is nothing more than a hypothesis among many - that his understanding greatly relies on his mental models that stem from his past experiences, his values, his emotions, etc. - he risks being stuck in his position and closed to the resolution of the problem. Newburg and Waldman [35] argue, as well, that if we are conscious that our mental model is nothing more than a hypothesis, a "guess", then we can remain open to the opinions and points of view of others without feeling threatened or upset. They add that the development of a holistic and systemic vision, as well as links to be made between our mental models and our perceptions, allow the team members to reach the state necessary to be disposed to the development of a common intelligence. Thus, the members of the team are no longer in opposition to one and other, they perceive each other as allies and can make discoveries or make decisions that, individually, they would not be able to.

Like these authors, we believe that to make room for a real collaborative effort with others, it is necessary to approach it through the development of this awakening to the awareness that our manner of interpreting is simply one of many possible ways that are just as valid $[44,20,13,42]$. The latter also promotes a greater sensitivity in the student in terms of the effect of their behavior on others and the effect that the behavior of others has on them. Furthermore, we think that the capacity to practice active listening, to develop emotional intelligence, to give and receive critical and constructive feedback, as well as resolving conflicts, depends largely on the awareness and the development of a holistic and systemic vision of the group.

\subsubsection{Group Models}

A model is a representation of the organization or the workings of something. This representation is generally proposed in the form of words and images. A road map, for example, will allow a driver to follow the main roads and find their way. It serves them, in a way, as a landmark, as a guide. Moreover, explaining the workings of the group demands the use of a representation of its principle elements and their function. The purpose of a group model, its usefulness, is to illustrate how a group is organized, and how its different elements interact with each other without, however, claiming to represent all of its complexity. Even if these models have their limits, they still facilitate a certain adaptation and intervention in the reality they represent. To establish a useful tool, we could say that a model, as a conceptual system, must meet a certain number of criteria. Firstly, it must organize the entirety of the data of the literature in a pertinent fashion. Next, its statements must be linked to our intersubjective experience of reality. Lastly, its hypotheses must be verifiable and modifiable [40]. We can add that "a good model is one that is capable of orienting the action" [30].

In the team work part of the course, we present 3 models of small groups capable of orienting the action: a 5 stage linear model [45], a systemic model in 3 zones [28] and a "constructivist" model of structures and functions [40]. Tuckman's model offers the first milestones for the understanding of the development of group dynamics. Figure 2 shows group development in 5 stages. 


\begin{tabular}{|c|c|c|c|c|}
\hline 1- Forming & 2- Storming & 3- Forming & 4- Performing & 5- Adjourning \\
\hline $\begin{array}{c}\text { Courtesy, prudence, } \\
\text { avoidance of serious } \\
\text { confrontation, little } \\
\text { definition of roles and } \\
\text { dependence on the leader. }\end{array}$ & $\begin{array}{c}\text { Tensions, } \\
\text { confrontations, } \\
\text { criticisms, defining of } \\
\text { group objectives and } \\
\text { the formation of } \\
\text { cliques and struggles } \\
\text { for power. }\end{array}$ & $\begin{array}{c}\text { Defining of roles and } \\
\text { duties, consolidation } \\
\text { of the "rules of the } \\
\text { game", greater } \\
\text { listening, } \\
\text { cooperation, } \\
\text { collaboration and } \\
\text { involvement. }\end{array}$ & $\begin{array}{c}\text { Confidence, } \\
\text { interdependence, } \\
\text { equilibrium of the group } \\
\text { between its task and } \\
\text { people-related goals, } \\
\text { challenges and creativity. } \\
\text { Many teams never reach } \\
\text { this stage. }\end{array}$ & $\begin{array}{c}\text { End of the task, disengagement, } \\
\text { diverse climate, anxiety, deception } \\
\text { or relief. The author reminds us of } \\
\text { the importance of paying particular } \\
\text { attention to ending the life of a } \\
\text { group. }\end{array}$ \\
\hline
\end{tabular}

Figure 2. Tuckman's Stages

The interesting thing about the Tuckman's model is that it allows a team to quickly situate itself in its development. It provides the team with the basic information to understand what is problematic in its current functioning and what can be done to improve it. For example, a newly formed team could, by identifying what characterizes stage 3 of the model, give itself the means to reach it more quickly. If, in the norming stage, the rules of the game are clear, cohesion is good and each member's role is clearly defined; it is the inverse for the forming stage, associated at the beginning of the life of the group. In fact, the latter is defined by a lack of clarity of the roles and the norms and a lack of cohesion that is displayed in the form of an exaggerated level of prudence in the members who fear to clearly state what they truly think. The team can decide, as a strategy of change, to discuss its norms and roles, so as to make them explicit for everyone in the group to improve its performance. It could decide to organize a lunch or even a group activity to improve the level of cohesion through getting to know each other better. Through these two actions alone, the team can give itself the means to pass through the stages and achieve greater efficiency. This first use of Tuckman's model by the students, sets the necessary foundation for the integration and understanding of the subsequent models [40, 28], of greater complexity.

\subsubsection{Proposed Actions for the Development of an Efficient Team Dynamic}

A team can define itself according to certain characteristics: 1 - small number of members: 3 to 20 [1, 28], 2- Face to face interactions, direct communications [1, 40, 28], 3- pursuit of goals valorized by members, common objectives [43, 1, 40, 28], 4- development of an emotional life [33, 1, 40, 28], 5- appearance of norms and roles [1, 40, 28] and 6- development of a structure of power [40, 28]. These characteristics and the models that stem from them help in the understanding of the elements at the heart of a group dynamic and its management. Thus, certain behaviors in a team setting are practiced within the framework of our training, in the courses themselves and through the follow up (or monitoring) in the engineering projects:

- agree on a common goal (the what) by clearly defining your tasks, your objectives and the way to attain them.
- develop good organization (the how) and regularly question yourself about it by conducting, among other things, a team feedback session at the end of each reunion on what went well and what needs to be improved.

- establish the working rules, explicit group norms.

- develop links between members, try to develop group cohesion (the climate); by giving, for example, individual and team feedback regularly.

- clearly define each person's role linked to a task and the organization of the task.

- verify the comprehension of the task by insuring that everyone understands what each person's job is by conducting a round table where each member presents the progress in their tasks and their understanding of what remains to be done.

- utilize each member's strengths, starting with the strengths identified by the individuals themselves, or still, by using tools such as group interaction methods [40].

\section{Monitoring of Teams in Integration Projects}

We believe that a 45 hour training course, centered on understanding and experimentation of interpersonal and team work communication phenomena and techniques is essential, but not enough to attain an adequate level of skills and competencies in the domain. This is why this basic training is a cornerstone of the organization and management of team work performed in integration projects, among others. The integration projects are projects of one session in which the students produce a team project in engineering. From the creation of a scale model of a bridge, to the production of a miniature robot, or even the design of an industrial product, the projects are as varied as the teams. A specialist in communications and team work conducts one visit per team for each integration project and allows the students to perfect their skills in this domain throughout the four years of their training. Figure 3 shows the monitoring of the teams offered in all Engineering programs at Polytechnique Montréal. 


\begin{tabular}{|c|c|}
\hline $\begin{array}{l}\text { Interventions are done in } 3 \\
\text { or } 4 \text { integration projects } \\
\text { per engineering program: }\end{array}$ & A specialist does: \\
\hline $\begin{array}{l}\text { Aerospatiale, Biomedical, } \\
\text { Chemical, Civil, Electrical, } \\
\text { Geological, Industrial, } \\
\text { Computer, Software, } \\
\text { Mechanical, Mining } \\
\text { Engineering and Engineering } \\
\text { Physics. }\end{array}$ & $\begin{array}{l}\text { - One visit per team } \\
\text { - One hour of coaching per team } \\
\text { - Personal interventions for } \\
\text { teams in difficulty (conflict) } \\
\text { - Tool available at the website: } \\
\text { www.hpr.polymtl.ca }\end{array}$ \\
\hline
\end{tabular}

Figure 3. monitoring of teams over 4 years

The monitoring is more than a simple managing of work processes and constitutes a central element of team work training. Group phenomena are "complex" [42] because of the singular dynamic of each team; the interaction of the individuals that compose the teams make each unique $[1,40$, 28]. During monitoring, the team work specialist must adapt and put their knowledge of theory and practice of small groups at the service of the team. Together, they bring the complexity of the performance of the team up-to-date. Consequently, the specialist does not make any decisions for the group, does not take on the role played by the team members, but rather supports them and provides the necessary tools to make the best choices for good group performance. Once the monitoring is completed, the team has a more precise vision of their singular dynamic, which promotes understanding and accountability of the students faced with their common tasks and objectives of individual change to be put into practice.

\subsection{General Monitoring}

Regular and varied monitoring are offered to the teams all through their studies. Two important types of monitoring are practiced: 1- "general" monitoring (the specialist acts as an instructor) and 2- "crisis management" type monitoring (the specialist acts as a mediator). The latter is offered when major problems arise in the group. "Generous" monitoring is offered to all teams during the integration projects. It promotes the transfer of learning of themes related to team work and the management of the group by team members. To do this, the specialist guides the group to reflect on its own dynamic so that they can assess their strengths as much as their weaknesses that need improvement. To achieve this, the specialist can use different strategies in order to probe the themes associated to each of the monitoring sessions. These strategies gradually touch upon three themes. Figure 4 presents the sequence of the themes covered during the monitoring sessions over the four year period.

\begin{tabular}{|c|c|c|c|}
\hline $\begin{array}{l}1^{\text {st }} \text { year: } \\
\text { Organization }\end{array}$ & $\begin{array}{l}2^{\text {nd }} \text { year: } \\
\text { Emotions }\end{array}$ & $\begin{array}{c}3^{\text {rd }} \text { year: } \\
\text { The General Dynamic of the } \\
\text { Group }\end{array}$ & $\begin{array}{l}4^{\text {th }} \text { year: } \\
\text { The General Dynamic of the Group }\end{array}$ \\
\hline $\begin{array}{l}\text { Time management, work } \\
\text { planning, separation of tasks, } \\
\text { physical and material } \\
\text { organization, appearance and } \\
\text { maintenance of norms related } \\
\text { roles. }\end{array}$ & $\begin{array}{l}\text { Cohesion, roles related to } \\
\text { emotions, creation of } \\
\text { sub-groups and their impact, } \\
\text { effects on climate and } \\
\text { common goals, emotional } \\
\text { norms, listening in groups } \\
\text { and resolution of problems. }\end{array}$ & $\begin{array}{l}\text { Equilibrium of the three dimensions } \\
\text { (organization, emotions, } \\
\text { power/leadership), methods of } \\
\text { interaction, roles and tasks, } \\
\text { leadership, group culture and } \\
\text { norms. }\end{array}$ & $\begin{array}{l}\text { Equilibrium of the three dimensions } \\
\text { (organization, emotions, } \\
\text { power/leadership), methods of } \\
\text { interaction, roles and tasks, leadership, } \\
\text { group culture and norms. }\end{array}$ \\
\hline $\begin{array}{l}\text { Objectives: } \\
\text { understanding the direct effects of } \\
\text { this organization on efficiency } \\
\text { and productivity of the group }\end{array}$ & $\begin{array}{l}\text { Objectives: } \\
\text { understanding the direct } \\
\text { effects of good management } \\
\text { of the climate on the } \\
\text { efficiency of group } \\
\text { performance. }\end{array}$ & $\begin{array}{l}\text { Objectives: } \\
\text { understanding the direct effects of } \\
\text { an overview of the group dynamics } \\
\text { and the application of concrete } \\
\text { actions to affect change in the } \\
\text { efficiency and performance of the } \\
\text { group. }\end{array}$ & $\begin{array}{l}\text { Objectives: } \\
\text { understanding the direct effects of an } \\
\text { overview of the group dynamics and } \\
\text { the application of concrete actions to } \\
\text { affect change in the efficiency and } \\
\text { performance of the group. }\end{array}$ \\
\hline
\end{tabular}

Figure 4. three types of "generous" monitoring

The sequence of the monitoring sessions has been elaborated with the goal of understanding the major elements of team work, to avoid redundancies and promote the progression of learning. As well as putting the emphasis on these central elements associated with each of the monitoring sessions, the specialist promotes the practice of critical and constructive feedback within the framework of the meetings. Depending on the needs of the group, the specialist can insist on the use of feedback focused on individuals or on the team. The specialist promotes the development of a systemic and comprehensive vision of the group and insists on the taking into account of the effect of interactions between group members on the individuals and on the development of the team. Furthermore, by the simple identification and defining of the strengths and weaknesses of the team, helps students to elucidate some problems in the group dynamic and the actions to be taken to improve the team's efficiency. Figure 5 shows an example of intervention in the first few years, working from strengths and weaknesses identified and defined by project team members. 


\begin{tabular}{|c|c|}
\hline Identified Strengths & Identified Weaknesses \\
\hline $\begin{array}{l}\text { Respect (politeness and flexibility for scheduling conflicts) } \\
\text { - } \quad \text { Good communication (e-mail is well-managed, because even if the team rarely } \\
\text { meets, the documents are well-prepared) } \\
\text { Efficiency (quick and efficient because their meetings never last long. } \\
\text { Everybody is focused on the task.) } \\
\text { *It is very important to ask the members to define and clarify their statements. }\end{array}$ & $\begin{array}{l}\text { Difficult to meet (lack of availability) } \\
\text { - } \\
\text { Many absences and frequent tardiness } \\
\text { Last minute (as concerns the task, which leads to } \\
\text { stress) } \\
\text { Lack of motivation } \\
\text { Little collaboration (everyone does their own task } \\
\text { and only concentrates on themselves. The members, } \\
\text { except for the project leader, cannot describe the } \\
\text { tasks of the others.) }\end{array}$ \\
\hline $\begin{array}{l}\text { Specialist's Analysis with the Team } \\
\text { - } \\
\text { Signs of a lack of cohesion: politeness, appear to want to finish as fast as } \\
\text { possible when they meet, absenteeism, tardiness, lack of motivation, little } \\
\text { collaboration and centralized communication (towards the project leader) as } \\
\text { opposed to decentralized. } \\
\text { Signs that norms are ill-defined: incoherencies between the identified strengths } \\
\text { (flexibility for absenteeism, rapidity of meetings) and the weaknesses } \\
\text { (difficulty to meet, absenteeism, tardiness, last minute). The members do not } \\
\text { share the same opinion. } \\
\text { Signs that the tasks are ill-defined: the tasks are done in separate ways. The } \\
\text { members do not know what the others are working on. Only the project leader } \\
\text { sees the whole picture. The group lacks motivation, probably because it does } \\
\text { not have a common objective, a common goal and an overall view of the work } \\
\text { with the exception of one member. }\end{array}$ & 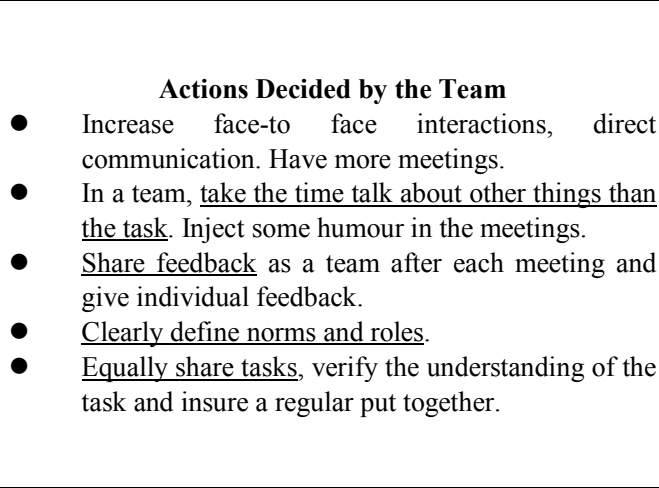 \\
\hline
\end{tabular}

Figure 5. an example of an intervention with a monitoring session for a project team

\section{Conclusions}

This article tried to explore what the parameters are, such as certain conditions, of the learning of collaborative work and of the development of skills for team work at Polytechnique Montréal. Answering this kind of query involved identifying and clarifying how we treat, enlightened by a certain review of the literature, certain key concepts, approaches and team work methods in our practice. Our review of the literature has allowed us to note the abundance of research in this field and to detect a coherence, so as to construct our learning model and competency development. Of course, this training model is not definitive or exclusive, other concepts, methods and approaches could be obviously possible. The possibility of using other ways, illustrates the complexity of the phenomenon that is the group, but especially the difficulties and interest that there are to attempt to find pedagogical methods for teaching and the development of competencies in this field, for our students. As Borrego, Karlin, McNair and Beddoes [9] states it in their research, this is the challenge that we attempt to meet in laying the foundations of a pedagogical approach in team work for disciplines other than Human Science. Finally, we think that it would be useful to validate our efforts for skills development in our students through an in-depth study of their team work competencies, as perceived by the employer, either of the student in job placement or of the junior engineer starting their career. Meanwhile, without claiming completeness, we can underline that our intern program has been compiling for several years the results of the student's internship in their working environments. Supervisors evaluating our students rated them as meeting or exceeding their expectations of teamwork skills. Also note that this training has received over the years 10 teaching awards or student recognition awards at Polytechnique Montréal. In 2011, a prestigious award was given to the training program for best communication at the International Conference on Engineering Education (ICEE) in Ireland. Finally, since 2015, we evaluate the student's teamwork skills in the first and last year of the curriculum. In 2019, we will have sufficient data to evaluate the impacts of the program over 4 years. The study of the effects of this training, within the framework of a wider ranging research, could certainly promote a greater advance of knowledge and a better accompanying (framework, guidance) of our students in the study of team work.

\section{REFERENCES}

[1] Anzieu, D. and Martin, J.-Y. (1994). La dynamique des groupes restreints, Paris, PUF.

[2] Arrow, H., McGrath, J.E. and Berdahl, J.L. (2000). Small Group as Complex Systems, Thousand Oaks, California, Sage Publications.

[3] Ashkanasy, N.M. and Daus, C.S. (2002). "Emotion in the Workplace: The New Challenge for Managers". Academy of Management Executive, Vol. 16(1), 76-86 pp.

[4] Assiter, A. (1995). Transferable Skills in Higher Education, London : Kogan Page.

[5] Bennett-Goleman, T. (2002). L'alchimie des emotions, Paris: Robert Laffont.

[6] Bohm, D., Factor, D. and P. Garrett (1991). Dialogue, a Proposal, Hawthorne Cottage, Broad Marson Lane, Mickelon, Glos. GL5 6SF, U.K. 
[7] Bohm, D. and Nichol, L. (1996). On Dialogue, New York: Routledge.

[8] Bormann, E.G. (1975). Discussion and Group Methods: Theory and Practice, HarperCollins Publishers.

[9] Borrego, M., Karlin, J., McNair, L. and Beddoes, K. (2013). Team effectiveness theory from industrial and organizational psychology applied to engineering student project teams: a research review, Journal of Engineering Education, Vol 102, No.4.

[10] Boyatzis, R. and McKee, A. (2006). Les nouveaux défis du leadership, ParisL Village Mondial.

[11] Caruso, D.R. and Salovey, P. (2004). The Emotionally Intelligent Manager, Jossey-Bass: San Francisco.

[12] Cook-Greuter, S. (2001). The Leadership Development Framework: Training for Consultants and Coaches, Wayland, MA : Harthill USA.

[13] Cook-Greuter, S. (2004). "Making the Case for a Developmental Perspective". Industrial and Commercial Training, 36(7), 275-281 pp.

[14] Cormier, S. (1995). La communication et la gestion, Sainte-Foy: Presses de l'université du Québec.

[15] Cormier, S. (2004) Dénouer les conflits relationnels en milieu de travail, Editions: Presses de l'Université du Québec.

[16] Davidson, N., Major, C., Michaelson, L. (2014). Team Based Learning Practices and Principles in Comparison with Cooperative Learning and based Learning. Journal on Excellence in College Teaching, 25 (4).

[17] Delong et Berg, I.K. (2003). De l'entretien à la solution, Bruxelles : Satas.

[18] Duncan, B. L. and Miller, S. D. (2000) The Heroic Client, San-Francisco : Jossey-Bass.

[19] Federman-Stein, R. (2000). "Using Student Teams in the Classroom”. A Faculty Guide, 203 pp.

[20] Fisher, W.R. (1987). Human Communication as Narration: Toward a Philosophy of Reason, Value and Action, Columbia, University of South Carolina Press.

[21] Fisher, D. and Torbert, W. (1991). "Transforming Managerial Practice : Beyond the Achiever Stage". Research in Organizational Change and Development, 5, 143-173 pp.

[22] Fisher, D., Rooke, D. and Torbert, W. (2000). Personal and Organisational Transformations through Action Inquiry. Boston : EdgeWork Press.

[23] Frith, C. (2007). Making Up the Mind : How the Brain Creates Our Mental World, Blackwell Publishing.

[24] Harvey L. \& Green, D. (1993) "Defining quality", Assessment and Evaluation in Higher Education, Vol.18, 8-35 pp.

[25] Hirokawa, R.Y. and Poole, M.S. (1996). Communication and Group Decision-Making, (2nd edition), Thousand Oaks, Sage.

[26] Goleman, D. (2009). Cultiver l'intelligence relationnelle. Éditions Laffont.
[27] Kegan R. (1994). In Over Our Heads: The Mental Demands of Modern Life. Cambridge, MA: Harvard University Press.

[28] Kourilsky-Belliard, F. (2004). Du désir au plaisir de changer: comprendre et provoquer le changement, Paris: Dunod, 3e edition.

[29] Landry, S. (2007). Travail, affection et pouvoir dans les groupes restreints: le modèle des trois zones dynamiques, Montréal, Les Presses de l'université du Québec.

[30] LittleJohn, S. W. et Foss, K. A. (2008). Theories of Human Communication, NINTH Edition.

[31] Miles, M.B. et Huberman, A.M. (1994). Analyse des données qualitative, (2003), Bruxelles, de boeck.

[32] Miller, S. D., Duncan, B. L., \& Hubble, M. A. (1997) Escape from Babel, New-York : Norton.

[33] Mongeau, P., Tremblay, J. (2005). Connaître votre profil et son effet sur les autres, Paris, Maxima, diffusion Presses Universitaires de France.

[34] Moreno, J. L. (1960). The Sociometry Reader, Glencoe, Illinois: The Free Press.

[35] Myers, G.E., Myers, M.T. (1980). Les bases de la communication interpersonnelle, Toronto : Mc Graw Hill.

[36] Newberg, A. and Waldman, M.R. (2006). Why We Believe What We Believe. Free Press.

[37] Peuker, S. and Mott, J. (2014). Implementing Team Based Learning in first-year engineering courses. California Polytechnic State University.

[38] Poole, M. (1999). "Group Communication Theory". in L. Frey, D. Gouran et M. Poole, The Handbook of Group Communication Theory and Research, Thousand Oaks, CA, Sage, 37-70 pp.

[39] Prochaska, J. O., DiClemente, C. C., \& Norcross, J. C. (1992) "In Search of How People Change". American Psychologist, 47, 1102-1114 pp.

[40] Rooke, D. and Torbert, W.R. (2005). "Seven Transformations of Leadership". Harvard Business Review, Vol. 83, Issue 4, 67-76 pp.

[41] Saint-Charles, J. and Mongeau, P. (2006). "Fondements d'un modèle communicationnel $\mathrm{du}$ groupe : structures et fonctions". in J. Saint-Charles et P. Mongeau, Communication : horizons de pratiques et de recherches, volume 2, Québec, Presse de l'Université du Québec, 191-208 pp.

[42] Sklare, Gerald B. (2004). Brief Counseling that Works. A Solution-focused Approach for School Counsellors, Sage Publications.

[43] Snowden, David J. and Boone, Mary E. (2007). A leader's Framework for a Decision Making, Harvard Bussiness Review, November 2007, pp.

[44] St-Arnaud, Y. (1978). Les petits groupes : participation et communication, (1989), Montréal, Les presses de l'université de Montréal; Les Editions du CIM. 
[45] Torbert, W. (1987). "Organizational Transformation as a Function of a CEO's Developmental Stage". Organisazation Development Journal, 16(1), 11-28 pp.

[46] Tuckman, B.W. and Jensen, M.A.C. (1977). "Stages of small-group development revisited". Group and Organizational Studies, vol. 2, no 4, 419-427 pp.

[47] Watzlawick, P. and Nardone, G. (2000). Stratégie de la thérapie brève, traduction française par L. Aubert, Paris, Seuil, 1997.

[48] Weisinger, H. (2006). L'art de la critique constructive. Les éditions transcontinentales.
[49] Wind, Y and Crook, C. (2005). The Power of Impossible Thinking : Transform the Business of Your Life and the Life of Your Business, Wharton School Publishing.

[50] Winkin, Y. (1981). La nouvelle communication, Bateson, Birdwhistell, Goffman, Hall, Jackson, Scheflen, Sigman, Watzlawick. Paris: Editions du Seuil.

[51] Young, J.E. (2002). “A Spectrum of Consciousness for CEOS: A business application of Wilber's Spectrum of Consciousness". The International Journal of Organizational Analysis, 10(1), 30-54 pp. 